\title{
Role of exposure to data collection and analysis activities during community orientation program and its effect on knowledge and attitude of medical undergraduate students
}

\section{Chethana Thirthahalli*, Radhika Kunnavil, Bhanu Manjunath, Nandagudi Srinivasa Murthy}

Department of Community Medicine, M. S. Ramaiah Medical College, Karnataka, India

Received: 09 September 2016

Accepted: 04 October 2016

*Correspondence:

Dr. Chethana Thirthahalli,

E-mail: chethana31@gmail.com

Copyright: (C) the author(s), publisher and licensee Medip Academy. This is an open-access article distributed under the terms of the Creative Commons Attribution Non-Commercial License, which permits unrestricted non-commercial use, distribution, and reproduction in any medium, provided the original work is properly cited.

\begin{abstract}
Background: The current medical education of health professionals is insufficient. There is a need for creating additional settings for health professional's education beyond four walls of medical college. Students during COP learn about research and health problems of community. The objectives was to evaluate role of exposure to data collection and analysis activities during Community orientation program [COP] and its effect on knowledge and attitude of medical undergraduate students of a Medical College.

Methods: Interventional study was carried out amongst the $3^{\text {rd }}$ and $4^{\text {th }}$ term undergraduate medical students between December 2014 and February 2015. A pretested semi structured questionnaire was administered on knowledge and attitude. Intervention consisted of didactic lectures and hands on exercises on data collection and data analysis. After 1 week of survey, post test was conducted.

Results: The study was completed by 125 (82.8\%). Lack of training was main barrier felt by $73 \%$ in pursuing research. It was noted that $59.2 \%$ had satisfactory knowledge score during pre-test, which increased to $78.4 \%$ in post test. Favorable attitude was seen among $90.4 \%$ of students in post-test. Majority of the students felt intervention to be useful.
\end{abstract}

Conclusions: COP is a good opportunity for inculcating concept of research methodology among students.

Keywords: Attitude, Community, Education, Knowledge, Medical students, Oriented, Research

\section{INTRODUCTION}

The major objective of medical schools is to prepare the students to resolve the problems of their communities at the level of individuals, families and the community ${ }^{1}$. The current medical education of the health professionals becomes insufficient as it does not prepare them for working in rural areas. There is a need for creating additional settings for health professional's education beyond the four walls of the medical college. Community-oriented medical education (COME) is defined as "education which is focused on population groups and individual persons taking into account the health needs of the community concerned" ${ }^{1}$. The annually conducted Community Orientation Program tries to make the future doctors more sensitive and responsive to needs of the rural and urban communities and society. The aim of the COP program conducted by the medical college is to provide value education; strengthen skill and attitude of the undergraduate students. During Community orientation program (COP) students are familiarized about different steps involved in conducting a community based epidemiological survey and thus they are provided with an exposure to research. Research is a careful investigation or inquiry, especially through scientific methods, aimed at searching new fact or verification of 
established facts under various situations. Purpose of research is to discover and develop an organized body of knowledge through application of scientific procedures ${ }^{2}$. Health research training has been recognized as an important component of medical education because the rapid expansion and progress in biomedical research is expected to transform medical care. ${ }^{3}$ Advances in biomedical research during the last decade have highlighted the necessity of attracting greater numbers of physicians to careers that include a research component. ${ }^{4}$ Research involves the process of planning, collection, compilation, analysis and meaningful interpretation of data. ${ }^{5,6}$ Students during their posting in COP learn about rural and urban life, environmental sanitation, socioeconomic conditions and health problems of the community.

The medical undergraduate students of the M S Ramaiah Medical College are exposed to didactic lectures on research methodology in the first and second terms. In the third term students are provided hands on experience in data collection and analysis through surveys in community orientation program. Appropriate data collection and analysis form an important component in research. The objective of the present communication was to evaluate the role of exposure to data collection and analysis activities during Community orientation program and its effect on knowledge and attitude of medical undergraduate students of M S Ramaiah Medical College.

\section{METHODS}

M S Ramaiah Medical College has been conducting Community Orientation Program since 2004 for the $3^{\text {rd }}$ and $4^{\text {th }}$ terms medical undergraduate students. The program is being conducted in the urban and rural field practice areas of the medical college. The Kaiwara PHC area is one of the rural field practice area for training of undergraduate and postgraduate medical students. This covers 22000 populations distributed in 18 villages. The present study was carried out amongst the $3^{\text {rd }}$ and $4^{\text {th }}$ term undergraduate medical students of the Medical College for a period of three months between December 2014 and February 2015. Around 150 students were taken to Kaiwara for the rural component of COP. The students were divided into 7 groups and underwent well planned urban and rural activities like social mapping, health education, health camps, family study, school health and conducting community survey. Each year survey is carried out on different health problems to acquaint them with the procedure for collecting the data employing the scientific methodology.

During the orientation program for COP sessions were conducted on research methodology, demographic survey, data collection and data analysis. A pretested semi structured questionnaire was employed to gather the information. Content validity of the questionnaire was assessed through the inputs from experts in the field. Written informed consent was taken from the participants. The questionnaire consisted of questions ongeneral information about the student, basic questions about research, previous studies under taken on research, knowledge on data collection, data analysis and questions on attitude. General information consisted of age, gender, term, and register number. There were 36 specific questions on knowledge and attitude pertaining to data collection and analysis of data. Knowledge on various aspects of data collection such as methods of data collection, type of interview, rapport building, and structure of questions were assessed. Knowledge on various aspects of data analysis primarily included aspects such as tabulation, graphical representation, and calculation of descriptive statistics and interpretation of the results. There were 15 questions on knowledge about data collection and data analysis. After the urban postings the students were taken to Kaiwara for the rural posting. Just before the rural posting all the students were made to gather in a class room and the pre-test questionnaire was administered under the supervision of the faculty. Each correct answer about knowledge was scored ' 1 ' and wrong answer was given ' 0 '. There were 21 questions on attitude which assessed their attitude towards research, data collection, and data analysis. The attitude was graded in a 5 point likert scale. Strongly disagree, disagree, neutral, agree, strongly agree were scored 1, 2, 3,4 and 5 respectively. The maximum score was 120 and minimum score was 21 for knowledge and attitude combined.

Later they had a ten day rural component in Kaiwara PHC area in which a survey was carried out on one of the designated days by the students related to basic socio demographic characteristics. The survey data was collected in pre-coded structured format. The data was thoroughly checked for missing components. All the students from the 7 groups were actively involved in house to house survey. After the data collection, the students were taught data entry by the postgraduate students and did data entry for their respective villages. Then with the support of faculty and postgraduate students, the data was analyzed by them.

After 1week of the survey, post test was conducted using the same questionnaire to assess their knowledge and attitude about data collection and data analysis. Matching of students for pre and post analysis was done using their unique identification numbers. Approval for the current study was taken from the institutional ethics committee.

\section{Statistical analysis}

All the quantitative variables were summarized using descriptive statistics such as mean and SD. All qualitative variables were expressed in terms of proportions. Mean and SD for the knowledge score and attitude score in pre and post test were computed separately, further based on the median scores the data was dichotomized and compared for statistical significance using Mc Nemars test. Analysis was carried out separately for those who 
had already undertaken any research activity. $\mathrm{P}<0.05$ was considered for statistically significant. Statistical analysis was done using SPSS 18.0 version.

\section{RESULTS}

\section{Demographic and other particulars}

In the present study 151 students participated. Pre and post test data were available for 125 students. The rest of the 26 students were not included as they were absent during the post test. Majority of the students were from third term $(83.5 \%)$. The study consisted of almost equal representation of males $67(50.4 \%)$ and female 58 $(49.6 \%)$ students. The mean age of the students was 19.65 (SD: 1.16) years.

The analysis of data regarding interest in scientific research revealed that more than eighty five percent of the students expressed interest in it. One fifth of the students $(20.8 \%)$ were pursuing research during the present study. ICMR Short Term Scheme (STS) Program is one of the research programs for medical undergraduates in India about which $86.4 \%$ (108) of the students were aware.

Lack of training was the main barrier perceived by the students for conducting research (Figure 1). The other barriers as expressed by the students were lack of time, funds, lack of guide. About $95 \%$ felt that research is important for undergraduate curriculum which is an important finding.

\section{Knowledge scores}

The knowledge scores were dichotomized based on the median value of pre-test scores. It was observed that $59.8 \%$ of the students had secured score of $\geq 8$ during the pre-test, which increased to $78.4 \%$ in the post test (Table
1). The difference was found to be statistically significant $(\mathrm{P}<0.001)$.

\section{Attitude scores}

Comparison of attitude scores of students is presented in the Table 2. In the pre-test $32 \%$ of the students had favourable attitude which improved to $90.4 \%$ in the post test and this was found to be statistically significant $(\mathrm{P}<0.001)$.

Table 1: Comparison of knowledge scores of the students for pre and post intervention.

\begin{tabular}{|lll|}
\hline Knowledge score & $\begin{array}{l}\text { Pre test } \\
\text { n }(\%)\end{array}$ & $\begin{array}{l}\text { Post test } \\
\text { n }(\%)\end{array}$ \\
\hline $\begin{array}{l}\text { Score }<8 \\
\text { (Satisfactory) }\end{array}$ & $51(40.8)$ & 27(21.6) \\
\hline $\begin{array}{l}\text { Score } \geq 8 \\
\text { (Highly satisfactory) }\end{array}$ & $74(59.2)$ & $98(78.4)$ \\
\hline Total no of students & 125 & 125 \\
\hline
\end{tabular}

*Statistically significant - Mc Nemars test $\mathrm{P}<0.001$.

Table 2: Comparison of attitude scores of the students pre and post intervention.

\begin{tabular}{|lll|}
\hline Attitude scores & $\begin{array}{l}\text { Pre-test } \\
\text { n (\%) }\end{array}$ & $\begin{array}{l}\text { Post-test } \\
\text { n }(\%)\end{array}$ \\
\hline$<60$ (unfavourable) & $85(68)$ & $12(9.6)$ \\
\hline$\geq 60$ (favourable) & $40(32)$ & $113(90.4)$ \\
\hline
\end{tabular}

*Statistically significant - Mc Nemars test $\mathrm{p}<0.001$.

\section{Subgroup analysis (students with prior research exposure versus those without)}

Among the total 125 students included for the study 26 (20.8\%) of them already had an exposure to scientific research. An attempt was made to analyse the results separately for the remaining 99 students.

Table 3: Distribution of students according to perception on various aspects of intervention.

\begin{tabular}{|lllllll|} 
& $\begin{array}{l}\text { Strongly disagree } \\
\mathbf{N}(\%)\end{array}$ & $\begin{array}{l}\text { Disagree } \\
\mathbf{N}(\%)\end{array}$ & $\begin{array}{l}\text { Neutral } \\
\mathbf{N}(\%)\end{array}$ & $\begin{array}{l}\text { Agree } \\
\mathbf{N}(\%)\end{array}$ & $\begin{array}{l}\text { Strongly agree } \\
\mathbf{N}(\%)\end{array}$ & Total \\
\hline $\begin{array}{l}\text { Usefulness of theory } \\
\text { session }\end{array}$ & $7(5.6)$ & $16(12.8)$ & $29(23.2)$ & $57(45.6)$ & $16(12.8)$ & $125(100 \%)$ \\
\hline $\begin{array}{l}\text { Usefulness of data } \\
\text { collection session }\end{array}$ & $1(0.8)$ & $2(1.6)$ & $10(8)$ & $74(59.2)$ & $38(30.4)$ & 125 \\
\hline $\begin{array}{l}\text { Usefulness of data entry } \\
\text { session }\end{array}$ & $1(0.8)$ & 0 & $8(6.4)$ & $80(64)$ & $36(28.8)$ & 125 \\
\hline $\begin{array}{l}\text { Usefulness of data } \\
\text { analysis session }\end{array}$ & $2(1.6)$ & $4(3.2)$ & $28(22.4)$ & $63(50.4)$ & $28(22.4)$ & 125 \\
\hline
\end{tabular}

The results of the 99 students showed that the median knowledge score was 8 (IQR:6-9) for pre-test and
9(IQR:8-10) for the post test. This difference in the scores were still found to be statistically significant $(\mathrm{P}<0.001)$. The percentage of students who had highly 
satisfactory knowledge (score >8) in the pre-test was $61.6 \%$ as compared to $80.8 \%$ in the post test. However, it was also observed that there was no statistically significant difference in their attitude, $33.3 \%$ had good attitude in pre-test and post-test it was $31.3 \%$.

Among the 26 students who had exposure to scientific research, $42.3 \%$ felt that lack of time was the main barrier in pursuing scientific research. The median knowledge score was 7.50 (6-9) in the pre-test and 9 (7-10) in the post test. This difference in the scores was also statistically significant $(\mathrm{P}=0.026)$. Around $50 \%$ of them had good knowledge in the pre-test as compared to $69.2 \%$ in the post test $(\mathrm{p}<0.001) .26 .9 \%$ had favourable attitude in the pre-test as compared to $76.9 \%$ in the post test $(\mathrm{p}<0.001)$.

After the intervention the student's perception about the usefulness of intervention was asked. The Table 3 shows their perception on various aspects of the intervention which was positive.

\section{DISCUSSION}

Biostatistics is an important scientific component of biomedical, public health and health services research ${ }^{7}$. Over the last few decades, bio-statistics has become more quantitative, stochastic, evidenced based with the growth of medical sciences and public health oriented research. The WHO SEARO has come up with guidelines for Public Health curriculum for teaching undergraduate students in which the stress upon research training is reiterated. $^{3,8}$

In India, medical students are not familiarized with public health research ${ }^{9}$. It is not reflected in their undergraduate curriculum and during post graduation the stress is more upon clinical skills. There is an urgent felt need for integrating scientific research training into undergraduate medical education. The medical students in India have limited options of research offered by the government such as the short-term scholarships supported by Indian Council of Medical Research (ICMR) and Kishore Vaigyanik ProtsahanYojana (KVPY). ${ }^{10}$

Community-oriented education programme has been adopted only by a very few medical colleges in the country. ${ }^{11-13}$ The experience of Community-oriented education has indicated that this activity has helped students to gain and understand and provided competencies in an incremental basis. Students learn the practice of community health and importance of involving the people for health action. Further such a real life situation has made it easy to understand principles of research methodology and various aspects involved including data analysis, interpretation of research data.

In the current study we utilized the setting of community orientation program to inculcate the ideas of research in our students. The students had theoretical sessions on research methodology. They were oriented about the survey and then were given a practical exposure of conducting a research. Real examples in which the students themselves participate in the collection of data and analyze would help them in better understanding and also interpreting the results of the study.

Although we had a group of students who were involved in scientific research during the study we did not find significant difference in their knowledge and attitude compared to the other group of students. This could be probably because of the small representation.

Class room teaching may not be sufficient for teaching research methodology. Dongre et $\mathrm{al}^{14}$ in their study also found that community based survey sensitizes the students to the importance of research and acts as a learning experience for their future work. Positive attitude has been observed among students towards such endeavor. $^{15}$

\section{Limitations}

The students could not be involved in the planning stage of the survey. The post test was done 1 week after the survey which is a short duration. This kind of interventions needs to be done repeatedly during the course of undergraduation to have more impact. Long term follow up of the students was not done.

\section{CONCLUSION}

The community orientation program is a good opportunity for inculcating the concept of research methodology among the students. This has been a learning experience for the faculty also. Similar work can be done by the other medical colleges. This will definitely go a long way in improving the public health research. There is a need for such interventions repeatedly so that they understand how to do the research projects. Small group discussions and projects would add to their knowledge.

Funding: No funding sources Conflict of interest: None declared

Ethical approval: The study was approved by the Institutional Ethics Committee

\section{REFERENCES}

1. Engel C. Annals of Community-Oriented Education, Volume 5. [Internet]. The Netherlands.: The Network of Community-Oriented Educational Institutions for Health Sciences; 1992 p. 11. Available from: http://files.eric.ed.gov/ fulltext/ ED358752.pdf

2. Rao NSN, Murthy NS. Applied Statistics in Health Sciences. $2^{\text {nd }}$ edition. Jaypee;2010. 
3. Scaria V. Whisking research into medical curriculum: the need to integrate research in undergraduate medical education to meet the future challenges. Calicut Medical Journal. 2004,2:e1

4. Zier K, Friedman E, Smith L. Supportive programs increase medical students' research interest and productivity. J Investig Med. 2006;54:201-7.

5. Mathew A, Murthy NS. A step towards quality medical research. National Medical $J$ India. 1998;11(6):283-6.

6. Heinekens $\mathrm{CH}$, Buring JE, Design strategies in epidemiologic research, 16-28: In: Mayrent (Eds). Epidemiology in Medicine, Little, Brown and Co. Boston/Toronto, 1987.

7. Biostatistics Network [Internet]. Department of statistical science. 2016 [cited 2 April 2016]. Available from: https://www.ucl.ac.uk/ statistics/ biostatistics-network

8. Guidelines for Preventive and Social Medicine/Community Medicine/Community Health Cur-riculum in the Undergraduate Medical Education. WHO SEARO 2010.

9. Isaacs AN. Strengthening research in Community Medicine. Indian J Community Medicine. 2007; 32(4):239-240.

10. Dangayach NS, Kulkarni UP, Panchabhai TS. Mentoring medical student research through studentships and fellowships: Reflections from India. J Postgrad Med. 2009;55:152-3.
11. Community Based Medical Education. Mgims.ac.in. 2016 [cited 2 April 2016]. Available from: https://www.mgims.ac.in/index.php/ community/ community-based-medical-education

12. St. John's National Academy of Health Sciences [Internet]. Stjohns.in. 2016 [cited 2 April 2016]. Available from: http://www.stjohns.in/about/

13. Abraham JS. Community-oriented medical education in Vellore, India. Academic Medicine LWW. 1993 [cited 2 April 2016]. Available from: http://journals.lww.com/academicmedicine/Abstract /1993/05000/Community_oriented_medical_educati on_in_Vellore,.5.aspx

14. Dongre AR, Kalaiselvan G, Mahalakshmy T. The benefits to medical undergraduates of expo-sure to community-based survey research. Educ Health (Abingdon). 2011;24:591.

15. Majumdar A, GK S, Roy G. Knowledge, Attitude and Perception of Medical Students Regarding Community-oriented Research. Natl J Community Med. 2015;6(2):230-5.

Cite this article as: Thirthahalli $\mathrm{C}$, Kunnavil R, Manjunath B, Murthy NS. Role of exposure to data collection and analysis activities during community orientation program and its effect on knowledge and attitude of medical undergraduate students. Int $\mathbf{J}$ Community Med Public Health 2016;3:3236-40. 